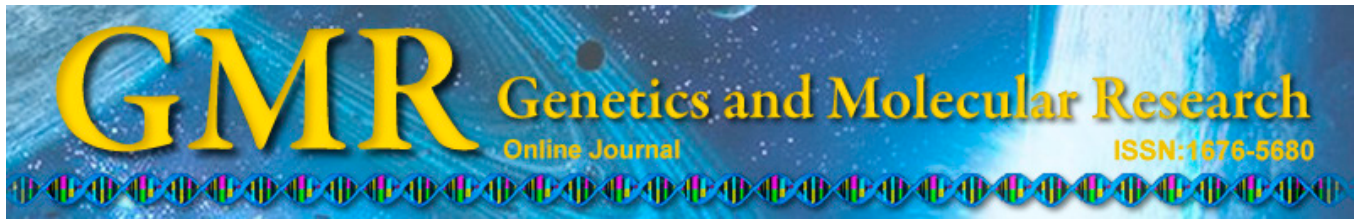

\title{
Sperm chromatin dispersion by formaldehyde in Wistar rats
}

N.D. Betancourt-Martínez ${ }^{1,5}$, J. Jiménez-Villarreal ${ }^{1}$, P. Carranza-Rosales ${ }^{2}$, N.E. Guzmán-Delgado ${ }^{3}$, C. Leyva Orasma ${ }^{4}$, E. Viveros Valdez ${ }^{5}$ and J. Morán-Martínez ${ }^{1}$

${ }^{1}$ Departamento de Biología Celular y Ultraestructura, Centro de Investigación Biomédica, Facultad de Medicina de Torreón, Universidad Autónoma de Coahuila, Torreón, Coahuila, México

${ }^{2}$ Departamento de Biología Celular y Molecular, Centro de Investigación Biomédica del Noreste, Instituto Mexicano del Seguro Social, Monterrey, Nuevo León, México ${ }^{3}$ División de Investigación, Unidad Médica de Alta Especialidad \#34, Instituto Mexicano del Seguro Social, Monterrey, Nuevo León, México ${ }^{4}$ Departamento de Ciencias Veterinarias, Universidad Autónoma Agraria Antonio Narro, Unidad Torreón, Coahuila, México

${ }^{5}$ Departamento de Química, Facultad de Ciencias Biológicas, Universidad Autónoma de Nuevo León, San Nicolás de los Garza, México

Corresponding author: J. Morán-Martinez

E-mail: javmoran@yahoo.com

Genet. Mol. Res. 14 (3): 10816-10826 (2015)

Received February 20, 2015

Accepted May 26, 2015

Published September 9, 2015

DOI http://dx.doi.org/10.4238/2015.September.9.20

ABSTRACT. Formaldehyde (FA) is an environmental xenobiotic, which is genotoxic and carcinogenic to humans and animals; it induces DNA damage, mutations, and clastogenicity during critical cytogenetic events. FA-mediated oxidative stress is an important mechanism that has been associated with the induction of cytotoxic and genotoxic damage. Therefore, the objective of this study was to evaluate the dispersion of sperm chromatin and reproductive parameters induced by exposure to 
different concentrations of FA in Wistar rats. Compared to the percentage of sperm with fragmented DNA in the control group $(18.10 \pm 8.62 \%)$, the percentage of sperm with fragmented DNA increased following exposure to 5,10 , and $30 \mathrm{mg} \mathrm{FA} / \mathrm{kg}$ body weight $(29.60 \pm 8.44,85.20 \pm 20.94$ and $96.0 \pm 7.87$, respectively; $\mathrm{P}=0.0001$ ). Histopathological alterations were evident, especially in the seminiferous tubules. In conclusion, this study provides experimental evidence concerning the genotoxicity of FA, with particular reference to the decreased sperm concentration and motility and increased dispersion of DNA chromatin in rats.

Key words: Formaldehyde; Sperm cells; Chromatin dispersion; Wistar rats; Histopathology

\section{INTRODUCTION}

Formaldehyde (FA) is a volatile low-molecular weight organic compound (Gurel et al., 2005). It is a flammable colorless gas at room temperature with a distinctive pungent odor. Other common names are methanal, methylene oxide, metaldehyde, and oxomethane, and it occurs naturally in the body in small quantities (ATSDR, 1999). FA is found in the environment because it is produced by various natural and anthropogenic sources (WHO, 1989; Liteplo et al., 2002). In occupational settings, exposure to FA mainly occurs by inhaling FA gas, but alternatively, can also occur by inhalation of paraformaldehyde particles or powder from resins and wood that contain FA (IARC, 1995). It has been estimated that the daily consumption and occupational exposure to FA is greater than $3 \mathrm{ppm}$ (WHO, 2000), while the endogenous concentration in rats, monkeys, and humans is $0.1 \mathrm{mM}$ (ATSDR, 1999; Lu et al., 2008; EPA, 2011). FA is a genotoxic agent that induces DNA damage; it is also carcinogenic and induces mutations and chromosomal aberrations in critical cytogenetic processes $(\mathrm{Lu}$ et al., 2008). The genotoxic damage caused by FA includes the formation of DNA monoadducts, DNA-DNA, and DNA-protein adducts, and the induction of clastogenicity, micronuclei, and sister chromatid exchange (Lu et al., 2010). Numerous investigations both in vitro and in vivo, for example, mutational studies in bacteria, DNA breaks, chromosome aberration, and acute or chronic exposure in laboratory animals, have demonstrated the genotoxicity of FA (Heck et al., 1982; Bolt, 1987). Moreover, it is known that the generation of reactive oxygen species (ROS) or inadequate protamine deposition during spermiogenesis can induce irreversible DNA damage in gametes (Manicardi et al., 1998), as well as apoptosis during sperm cell maturation (Cortés-Gutiérrez et al., 2007). Protamines are proteins that are folded into the DNA of sperm cells. They are of great importance for the compaction of DNA in the nucleus because of their arginine-containing residues (Ward and Coffey, 1991; Ward, 1993). The longitudinal binding of protamines along the grooves of DNA is mediated by these positively charged arginine residues, which neutralize the negative charge of phosphodiester bonds in the DNA strands (Ward, 1993). Balhorn (1982) described the importance of disulfide bonds in the chromatin compaction of spermatic cells, which was different from that of somatic cells as described by Ward and Coffey (1991). Both researchers demonstrated that DNA is 6-fold more compacted in sperm than that in mitotic chromosomes, and that it is arranged in smaller loops in spermatic cells than that in somatic cells and anchored to a nuclear matrix. These loops are compacted through intercropping with protamines, which rigidly stabilize their structure through disulfide 
bonds. If these bonds are broken, the DNA loops relax and form DNA halos around the central residual nuclear structure (Fernández et al., 2003; Cortés-Gutiérrez et al., 2007). In contrast to sperm with intact DNA, sperm cells that have fragmented DNA do not release, the DNA loops after acid treatment, and can be seen to have very small or no halos (Balhorn, 1982; Ward and Coffey, 1991; Ward, 1993; Fernández et al., 2003; Zribi et al., 2011). Exposure of spermatozoa to high concentrations of ROS can induce DNA fragmentation (Treulen et al., 2015). The major factors responsible for DNA damage in sperm cells are defects in chromatin compaction resulting from insufficient protamination, ROS production, and apoptosis induction (Agarwal and Allamaneni, 2005; Cortés-Gutiérrez et al., 2007; Gil-Villa et al., 2007). The induction of oxidative stress and the systemic formation of ROS have already been reported to be associated with the genotoxic mechanism of FA (Duong et al., 2011; Lino-dos-Santos-Franco et al., 2011; Tajaddini et al., 2014). The objective of this study was to evaluate the dispersion of sperm chromatin, spermatic parameters, genotoxic effect, and morphological alterations induced by different concentrations of FA in male Wistar rats.

\section{MATERIAL AND METHODS}

\section{Animals}

Twenty male, homozygous, pathogen-free, 5-6-week-old Wistar rats weighing 226$258 \mathrm{~g}$ were used. The animals were provided by the bioterium of the School of Dentistry, Autonomous University of Coahuila, Torreon Unit, in Torreon, Mexico. All animals were maintained under controlled temperature conditions of $25^{\circ}-26^{\circ} \mathrm{C}$, with a relative humidity of $30-70 \%$, and $12 \mathrm{~h}$ light and dark cycles. The animals were fed NUTRI CUBOS ${ }^{\circledR}$ (Agribrands Purina Mexico, S.A. de C.V., Mexico City, Mexico) and provided water ad libitum. This study was conducted in accordance with institutional and international guidelines for animal handling procedures (SAGARPA in Mexico, NOM-062-ZOO, 1999), and was approved by the Bioethics Committee of the School of Medicine of the Autonomous University of Coahuila, Campus Torreon, Coahuila, Mexico No. (approval by Secretaría de Salud and Comisión Nacional de Bioética in Mexico No. CONBIOETICA07CEI00320131015). Protocol approval reference No. AUT.02-08/13.

\section{Experimental groups}

Animals $(\mathrm{N}=20)$ were randomly divided into 4 groups of 5 rats each (control group, and treatment groups 1, 2 and 3). The control group received an intraperitoneal (ip) injection of $0.9 \%$ saline solution. Groups 1, 2, and 3 received daily an ip injection of 5, 10, and $30 \mathrm{mg}$ FA/kg body weight, respectively, for 5 days. After treatment, the animals were sacrificed by cervical dislocation and the organs and biological samples were collected for the relevant assays. All procedures were performed according to institutional and international guidelines on the care and handling of animals for experimentation.

\section{Sperm collection from the epididymis}

Sperm cells from the epididymis of the rats were collected in test tubes and washed once with $3 \mathrm{~mL}$ saline $(0.9 \% \mathrm{NaCl})$, then washed again with Ham F-10 medium (Invitrogen, 
Grand Island, NY, USA) and incubated at $37^{\circ} \mathrm{C}$ for $30 \mathrm{~min}$. The analysis of sperm parameters was carried out using bright-field microscopy according to the procedures described by Zhou et al. (2006).

\section{Epididymal sperm count and motility}

In order to determine the number of spermatozoa and the percentage of motile sperm, a drop of the sperm cell suspension, prepared from the epididymis as described above, was placed in a Neubauer chamber and the number of spermatozoa was counted in 10 different microscopic fields. For the analysis of total motility, 200 sperm were evaluated per sample at $100 \mathrm{X}$ magnification and the percentage was calculated according to the method described by Zhou et al. (2006).

\section{Sperm chromatin dispersion (SCD) test}

SCD in sperm cells was determined according to the methodology described by Fernández et al. (2003); this method can distinguish differentiating sperm with fragmented DNA from those with intact DNA. Briefly, cellular suspensions, 5-10 x $10^{6}$ cells $/ \mathrm{mL}$, were prepared from each sample and mixed with $1 \%$ low-melting point agarose at $37^{\circ} \mathrm{C}$, to obtain a final agarose concentration of $0.7 \%$ in distilled water. Subsequently, $50-\mu \mathrm{L}$ aliquots of the mixture were placed on glass slides that had been pretreated with $0.65 \%$ regular agarose and dried at $80^{\circ} \mathrm{C}$. A coverslip was then placed on the slide and the agarose was allowed to solidify at $4^{\circ} \mathrm{C}$ for $4 \mathrm{~min}$. Then, the coverslip was carefully removed, and the slides were immersed in a denaturing solution $(0.08 \mathrm{M} \mathrm{HCl})$ for $7 \mathrm{~min}$ in the dark. The slides were then transferred to \#1 lysis solution at $\mathrm{pH} 7.5$ (0.4 M Tris, 0.4 M DTT, 1\% SDS, $50 \mathrm{mM}$ EDTA) for $10 \mathrm{~min}$ and then to a neutralizing solution $(0.09 \mathrm{M}$ Tris-borate, $0.02 \mathrm{M}$ EDTA, $\mathrm{pH}$ 7.0), and afterwards, to \#2 lysis solution (0.4 M Tris, $2 \mathrm{M} \mathrm{NaCl}, 1 \% \mathrm{SDS}, \mathrm{pH}$ 7.5) for $5 \mathrm{~min}$. They were then washed in $0.09 \mathrm{M}$ Tris-borate, $0.002 \mathrm{M}$ EDTA buffer, $\mathrm{pH}$ 7.5 , for $2 \mathrm{~min}$, before being dehydrated in a sequential gradient of 70,90 , and $100 \%$ ethanol for $2 \mathrm{~min}$ each, and allowed to dry. The entire process from denaturation to dehydration and drying of the slides was performed at room temperature. Slides were stained with Wright:PBS solution (1:1). The surface of the slide was covered with an excess of dye and incubated for 10-15 min with occasional gentle mixing to achieve homogeneity. The slides were then washed gently with tap water and allowed to dry for analysis by bright-field light microscopy.

$\mathrm{SCD}=$ number of sperm with fragmented DNA / total number of sperm x 100.

\section{Histopathological analysis}

In order to study the effects of FA at the tissue level, the animals were sacrificed by cervical dislocation once treatment with FA was completed and then the organs were dissected out and fixed in $10 \%$ neutral formalin. Tissues were processed by conventional histological techniques and were embedded in paraffin blocks. Sections of $5 \mu \mathrm{m}$ were prepared on a microtome and stained with hematoxylin and eosin. After staining, the sections were mounted with synthetic resin and coverslips and were analyzed by light microscopy. 


\section{Statistical analysis}

The SPSS 20.0 statistical program for Windows was used for statistical analysis. Data were analyzed using descriptive statistics and are reported as average \pm standard deviation. Differences and distribution among the four groups were evaluated using the nonparametric one-sample Kolmogorov-Smirnov test. Because the data did not show a normal distribution, one-way ANOVA and the Tukey post hoc test were performed in order to compare the treatments. $\mathrm{P}<0.05$ was considered to be statistically significant for all tests applied. Additionally, Pearson's chi-squared bivariate correlation analysis was used to infer the strength of the relationship between independent variables and response variables.

\section{RESULTS}

\section{Experimental groups}

A marked effect was observed on the body weight of animals treated with different concentrations of FA. While the weight of animals in the control group and group 1 increased by an average of 11.6 and $7.8 \mathrm{~g}$, respectively, the weight of the animals treated with 10 and $30 \mathrm{mg} \mathrm{FA} / \mathrm{kg}$ decreased by an average of 11.4 and $23.4 \mathrm{~g}$, respectively, by the end of the experimental period.

The average values for the initial and final weights are shown in Table 1. Significant differences were found in the body weight of the three groups treated with FA, compared to the control $(\mathrm{P}=0.042)$; however, the Tukey post hoc test showed significant differences $(\mathrm{P}<$ 0.035 ) only between the body weights of groups 2 and 3 (Table 1).

Table 1. Comparison of biological parameters between formaldehyde-treated and control group.

\begin{tabular}{lccccc}
\hline Experimental groups & Basal body weight $(\mathrm{g})$ & Final body weight $(\mathrm{g})$ & Sperm cells $\left(\mathrm{x} 10^{6}\right)$ & Motility $(\%)$ & DNA fragmentation $(\%)$ \\
\hline Control $(0 \mathrm{mg} / \mathrm{FA})$ & $204.20 \pm 1.924$ & $215.8 \pm 2.86$ & $39.40 \pm 16.13$ & $45.60 \pm 9.99$ & $18.10 \pm 8.62$ \\
Group 1 (5 mg/FA) & $214.60 \pm 18.447$ & $222.4 \pm 17.05$ & $27.60 \pm 6.38$ & $2.80 \pm 0.837$ & $29.60 \pm 8.44$ \\
Group 2 (10 mg/FA) & $220.00 \pm 13.191$ & $208.6 \pm 11.14$ & $26.40 \pm 12.09$ & $1 \pm 0.57$ & $85.20 \pm 20.94$ \\
Group 3 (30 mg/FA) & $268.00 \pm 37.195$ & $244.6 \pm 31.26$ & $14.60 \pm 3.42$ & $0.0 \pm 0.0$ & $96.0 \pm 7.87$ \\
Control vs Group 1 & 0.874 & 0.943 & 0.466 & $0.0001^{* *}$ & 0.500 \\
Control vs Group 2 & 0.668 & 0.928 & 0.385 & $0.0001^{* *}$ & $0.0001 * *$ \\
Control vs Group 3 & $0.001^{* *}$ & 0.110 & $0.030^{*}$ & $0.0001^{* *}$ & $0.0001^{* *}$ \\
Group 1 vs Group 2 & 0.979 & 0.656 & 0.999 & 0.942 & $0.0001^{* *}$ \\
Group 1 vs Group 3 & $0.007^{* *}$ & 0.277 & 0.385 & 0.818 & $0.0001^{* *}$ \\
Group 2 vs Group 3 & $0.015^{*}$ & $0.035^{*}$ & 0.466 & 0.989 & 0.500 \\
\hline
\end{tabular}

*Significant statistical differences $\left(\mathrm{P}<0.05\right.$; Tukey post hoc test). ${ }^{*}$ Significant statistical differences $(\mathrm{P}<0.01$; Tukey post hoc test).

\section{Concentration of spermatic cells}

The concentration of sperm cells obtained from the epididymides of the control group and treatment groups 1, 2, and 3 was $39.40 \pm 16.13,27.60 \pm 6.38,26.40 \pm 12.09$, and 14.60 $\pm 3.42 \times 10^{6}$ cells $/ \mathrm{mL}$, respectively. FA reduced the sperm cell concentration in the treated groups, with the most notable effect observed in animals receiving $30 \mathrm{mg} / \mathrm{kg}$ FA. Significant differences were observed in the concentration of sperm cells between the treated groups and 
the control $(\mathrm{P}=0.049)$; however, the Tukey post hoc test showed a significant difference only between the control group and group $3(\mathrm{P}=0.030)$. The differences in sperm cell count between the different treatments are shown in Table 1.

\section{Motility}

Compared to the sperm motility in the control group (45.60 $\pm 9.99 \%)$, FA markedly decreased sperm motility of all animals in the 3 treatment groups, $2.80 \pm 0.837 \%$ for group $1,1 \pm 0.57 \%$ for group 2 , and $0.0 \pm 0.0 \%$ for group 3 . It is clear that the decrease in sperm motility is directly proportional to the concentration of FA administered (Table 1). Statistically significant differences in the sperm motility were observed among the four groups $(\mathrm{P}=0.0001)$ and the Tukey post hoc test confirmed these differences.

\section{Percentage of DNA fragmentation (SCD)}

The percentage of sperm cells with fragmented DNA in the control group and those in groups 1,2 and 3 were $18.10 \pm 8.62 \%, 29.60 \pm 8.44 \%, 85.20 \pm 20.94 \%$, and $96.0 \pm 7.87 \%$, respectively (Table 1).

FA induced DNA fragmentation in increased number of sperm cells in all the 3 treatment groups. Statistically significant differences were observed in the percentage of sperm cells with fragmented DNA (SCD) between groups treated with FA $v s$ the control group $(\mathrm{P}=0.0001)$. The Tukey post hoc test confirmed this significance $(\mathrm{P}=0.0001)$. The difference in the percentage of sperm cells with fragmented DNA between experimental groups is shown in Table 1, which shows that higher concentration of FA is correlated with increased DNA fragmentation in the sperm cells. After staining the slides with Wright solution, the structure of the halos of the sperm cells in the samples from the different experimental groups was analyzed. The effect of FA on sperm chromatin dispersion is directly proportional to the concentration of FA, as evidenced by the presence of small halos signifying degraded DNA at 10 and $30 \mathrm{mg}$ FA (Figure 1).
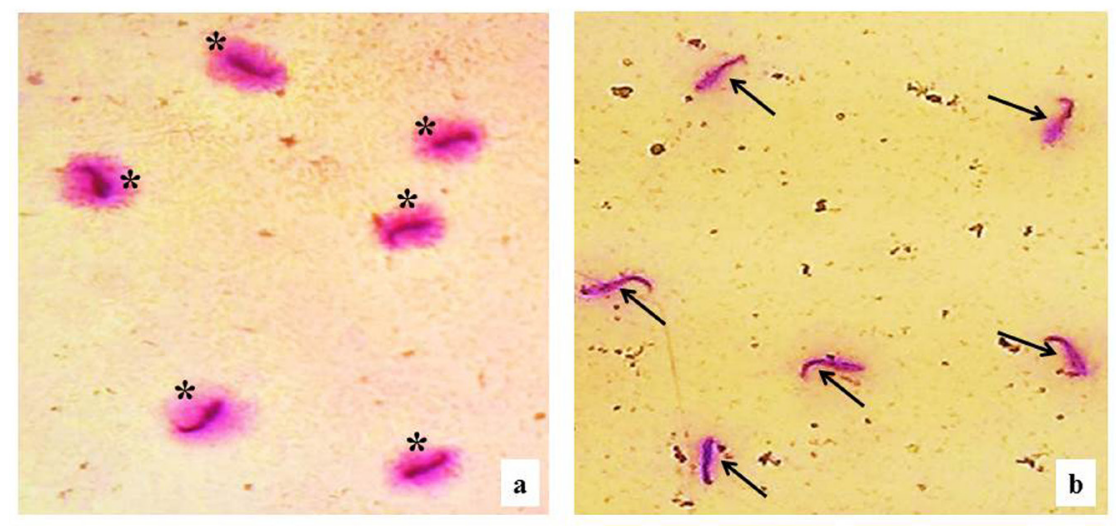

Figure 1. DNA fragmentation induced by formaldehyde in Wistar rat spermatozoa. a. Spermatozoa with fragmented DNA (asterisks) show chromatin dispersion around the core. b. Spermatozoa with unfragmented DNA do not show chromatin dispersion around the core (arrows). 


\section{Histopathological findings}

Histopathological analysis of the liver, kidneys, brain and lungs of the different experimental groups showed only systemic vascular congestion relative to the control at all FA concentrations tested (data not shown). The most notable effect was on the testicular tissue; however, it is important to note that the morphological alterations observed in tissues from animals treated with 5 and $10 \mathrm{mg} \mathrm{FA} / \mathrm{kg}$ body weight were graded only from mild to moderate. In contrast, in animals treated with $30 \mathrm{mg} \mathrm{FA} / \mathrm{kg}$ body weight, there was a marked decrease in the number of sperm cells, and the morphology of majority of the seminiferous tubules was altered: the germinal epithelium was characterized by desquamation and necrotic cell death in the superficial layers, degeneration of germinative cells and Leydig cells, focal hemorrhage, and deposits of amorphous intraluminal proteinaceous materials (Figure 2).
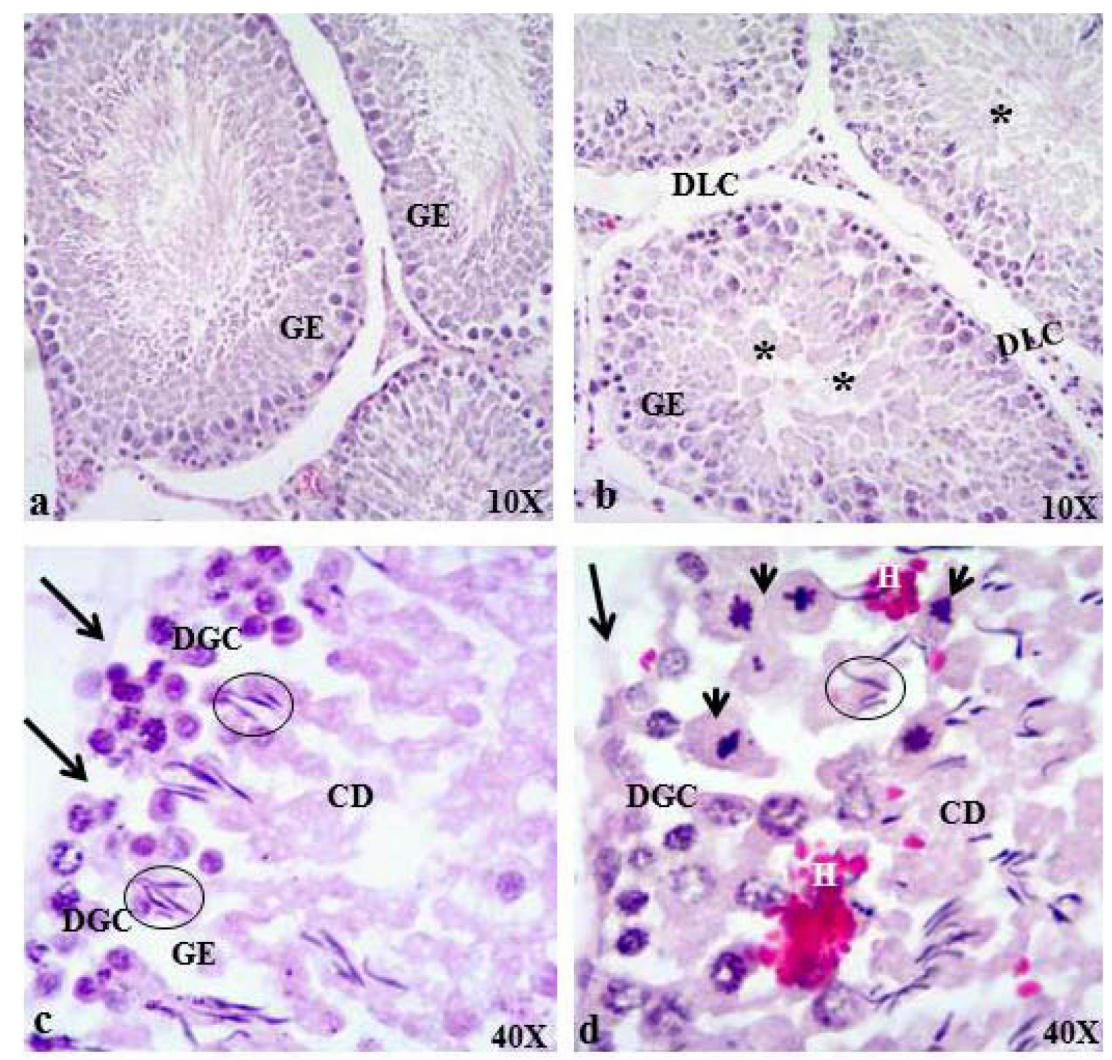

Figure 2. Effects of formaldehyde on testicular histopathology. Compared with the control group (a), significant histopathological changes were found in the groups treated with FA, with the most notable effect observed in group 3 , treated with $30 \mathrm{mg} \mathrm{FA} / \mathrm{kg}$ body weight (b). Morphological alterations in the germinal epithelium (GE) consisted of degeneration of both, germ cells (DGC) and Leydig cells (DLC), as well as deposits of amorphous-proteinaceous material in the lumen of the majority of the seminiferous tubules $\left(^{*}\right)$. At a higher magnification, (c) and (d) cellular death (CD), impaired spermatogenesis with atypical mitosis (small arrows), hemorrhage (H), decreased amount of sperm cells (circles), and disruption of the lining membrane of the seminiferous tubule (arrows) can be clearly seen after being stained with hematoxylin and eosin. 


\section{Correlations}

Compared to the corresponding values in the control group, the different FA treatments decreased the sperm cell count and sperm motility by $59.4 \%(\mathrm{P}=0.006)$ and $78.5 \%(\mathrm{P}=$ $0.0001)$, respectively, and increased the DNA fragmentation in sperm samples by $90.6 \%(\mathrm{P}=$ 0.0001 ). The results were statistically significant (Table 2).

Table 2. Statistical correlation between the formaldehyde concentrations vs biological parameters studied.

\begin{tabular}{lcccc}
\hline & Final body weight $(\mathrm{g})$ & Sperm cells $\left(10 \times 10^{6}\right)$ & Motility $(\%)$ & DNA fragmentation $(\%)$ \\
\hline ANOVA & $0.042^{*}$ & $0.049^{*}$ & $0.0001^{* *}$ & $0.0001^{* *}$ \\
Correlation & & $\mathrm{r}=-0.594$ & $\mathrm{r}=-0.785$ & $\mathrm{r}=0.906$ \\
P value & & $0.006^{* *}$ & $0.0001^{* *}$ & $0.0001^{* *}$ \\
\hline
\end{tabular}

*Statistical significant correlation: $\mathrm{P}<0.05$ (two-tailed). **Highly statistical significant correlation: $\mathrm{P}<0.05$ (two-tailed).

\section{DISCUSSION}

Our results show that the FA concentrations used in this study cause genotoxic damage to rat sperm cells and corroborate previous findings about the mutagenic effects of acute exposure to FA in laboratory animals (Majumder and Kumar, 1995; Tang et al., 2003; Zahra et al., 2007). It is particularly important to bear this in mind considering the increase in air pollution in urban and industrial areas in recent decades. Although many air pollutants, including FA, are genotoxic, their relationship with alterations and mutations found in the human male germ line have not yet been clearly established (Somers and Cooper, 2009). A study by Zhang et al. (2011), reported that acute exposure to FA affected the sexual behavior of adult male rats, and testosterone levels decreased in a time- and concentrationdependent manner in the groups tested. An evaluation of animal studies reporting different routes of administration, doses, and dosing regimens, suggested a direct association between FA exposure and reproductive toxicity, especially in men. Potential mechanisms underlying formaldehyde-induced reproductive and developmental toxicities, including chromosome and DNA damage (genotoxicity), oxidative stress, altered level and/or function of enzymes, hormones and proteins, apoptosis, toxicogenomic and epigenomic effects (such as DNA methylation) have been identified (Duong et al., 2011). With regard to the adverse effects of FA on reproductive outcomes, Wang et al. (2012) reported a significant increased risk of prolonged time to pregnancy and significant elevated risk of spontaneous abortion in the partners of occupationally exposed individuals.

With respect to oxidative stress, induction of ROS is one of the most important factors causing irreversible DNA damage and fragmentation in sperm cells, and may affect the process of maturation of gametes (Cortés-Gutiérrez et al., 2007). FA-induced ROS may cause alterations in plasma membranes, lipids, proteins, and nucleic acids (Gurel et al., 2005), which might explain the damage to the cell membrane of the sperm cells evaluated in the present study (data not shown). Moreover, statistically significant differences were observed in the weight of rats treated with 10 and $30 \mathrm{mg} / \mathrm{kg} \mathrm{FA}$, compared to that of the control, while the animals treated with $5 \mathrm{mg} / \mathrm{kg}$ FA gained weight. Similar results were reported by Johannsen et al. (1986) and Til et al. (1989). In general, the sperm concentration in the FA-treated groups decreased $(51 \%)$ compared to that in the control group. These findings are similar 
to those described by Majumder and Kumar (1995), who reported a 50\% decrease in sperm concentration in rats injected intraperitoneally with $10 \mathrm{mg} \mathrm{FA} / \mathrm{kg}$ body weight and Cassidy et al. (1983) who found a significant decrease in sperm counts in Wistar rats administered 100 to $200 \mathrm{mg}$ FA/kg orally. Similarly, Zhou et al. (2006) reported a reduction in sperm concentration and quality, as well as in testicular weight in rats exposed to FA vapors at a concentration of $10 \mathrm{mg} / \mathrm{m}^{3}$ for 2 weeks. In a study by Tang et al. (2003), toxicity and damage to the genetic material of germ cells was observed in male rats exposed to doses of $0.2,2$, and $20 \mathrm{mg} \mathrm{FA} / \mathrm{kg}$, administered intraperitoneally for a period of 5 days. The main pathological changes included degeneration of testicular tissue, decreased sperm count, and morphological changes in the sperm head in all the exposed groups. They also found a significant reduction in copper and zinc levels in the testicular tissue of the groups exposed to the highest concentration of FA. The decreased levels of zinc affect the formation of the cell membrane and the compaction of the quaternary structure of chromatin, while the reduction in $\mathrm{Cu}$ levels decreases cell energy thereby affecting sperm motility and the antioxidant function of seminal plasma. In our study, significant effects were observed on the external characteristics of the testes of rats; a flaccid consistency (plasmolysis) as well as dark blue color of the scrotum were observed in the group exposed to the highest concentration of FA (data not shown). This suggests a direct effect on testicular tissue. Although we did not determine the concentrations of $\mathrm{Zn}$ and $\mathrm{Cu}$, these metals may influence sperm motility and viability by affecting the testicular tissue, as proposed by Tang et al. (2003). In a related report, Zahra et al. (2007) described effects of intraperitoneal administration of $0,2.5,5.0,7.5$, and $10 \mathrm{mg} / \mathrm{kg}$ FA for 40 days on body weight, gonadosomatic index, reduced sperm fertility, motility, and viability of Wistar rats. In our study, a direct relationship between the decrease in body weight and the dose of FA was observed, as well as an effect on other variables associated with the quality of sperm. We also found a direct relationship between the toxic effect of FA on sperm DNA and damage to the genomic integrity of cells. Our findings strengthen the hypothesis that exposure to FA results in damage to reproductive health. Gametogenetic defects associated with the initiation of spermatogenesis were demonstrated in a study by Duong et al. (2011), which evaluated the reproductive toxicity of FA in male rats by DNA methylation assays. Furthermore, the reproductive toxicity in 30 male Sprague-Dawley rats exposed to $0,0.5$, and $2.46 \mathrm{mg} / \mathrm{m}^{3}$ FA vapor for 60 consecutive days was found to be directly related to the dose (Zhou et al., 2011). The structure and function of the epididymides of the testes in rats exposed to $0.5 \mathrm{mg} /$ $\mathrm{m}^{3}$ FA showed no obvious differences from those of the control group; however, the quality and quantity of sperm, testes, and the diameter of the seminiferous tubules, as well as the activity of superoxide dismutase and glutathione peroxidase significantly reduced in the group of rats exposed to $2.46 \mathrm{mg} / \mathrm{m}^{3} \mathrm{FA}$ compared with those in the control group. FA cytotoxicity increases the degree of interaction of nucleic acids with other molecules. This favors DNA methylation, adduct formation, reduced motility, and oxidative stress, all of which are linked to DNA fragmentation in sperm cells. With respect to our histopathologic analysis, the fact that no alterations in organs such as the liver, kidney, brain, and lungs were observed may be attributed to the short time of exposure to FA. In another study (Golalipour et al., 2009), no kidney damage was observed in rats exposed to FA vapors in cadaver-dissecting rooms. Regarding testicular damage induced by FA, some studies (Zhou et al., 2006; Vosoughi et al., 2012) reported similar results to those found in our study, while another report (Golalipour et al., 2007) described testicular damage after chronic exposure to FA vapors. The morphologic 
changes described in the present study can be correlated with the alterations in reproductive parameters and sperm chromatin dispersion. In conclusion, this study by evaluating chromatin dispersion and reproductive parameters in male Wistar rats demonstrates the genotoxicity of FA to be directly related to the decrease in sperm concentration and motility as well as with increased DNA fragmentation.

\section{Conflicts of interests}

The authors declare no conflict of interest.

\section{ACKNOWLEDGMENTS}

J. Jimenez-Villarreal and N.D. Betancourt-Martínez were supported by CONACyT scholarships (\#268684 and \#216334, respectively). We thank the academic training of J. Jimenez-Villarreal, the COECYT, CONACYT and PIFI Federal program for a research travel grant at A Coruña (Biomedical Research Institute) and Madrid (Genetics Department, Autonomous of Madrid University, Cantoblanco) Spain. J. Morán Martínez was supported by Fogarty International Center CareerTrac, School of Public Health, University of California at Los Angeles (Grant \#D43TW623; Program Name: ITREOH). We thank Coordinación General de Estudios de Posgrado e Investigación of the Universidad Autónoma de Coahuila for partial support of the study.

\section{REFERENCES}

Agarwal A and Allamaneni SSR (2005). Alteraciones de la cromatina espermática en la etiopatogenia de la infertilidad masculina. Rev. Int. Androl. 3: 31-37.

ATSDR (Agency for Toxic Substances and Disease Registry) (1999). Toxicological Profile of Formaldehyde. Available at [http://www.atsdr.cdc.gov/toxprofiles/tp111.pdf]. Accessed January 21, 2015.

Balhorn A (1982). Model for the structure of chromatin in mammalian sperm. J. Cell Biol. 93: 298-305.

Bolt HM (1987). Experimental toxicology of formaldehyde. J. Cancer Res. Clin. Oncol. 113: 305-309.

Cassidy SL, Dix KM and Jenkins T (1983). Evaluation of a testicular sperm head counting technique using rats exposed to dimethoxyethyl phthalate (DMEP), glycerol amonochlorohydrin $(\mathrm{GMCH})$, epichiorohydrin $(\mathrm{ECH})$, formaldehyde (FA), or methyl methanesulphonate (MMS). Arch. Toxicol. 53: 71-78.

Cortés-Gutiérrez EI, Dávila-Rodríguez MI, López-Fernández C, Fernández JL, et al. (2007). Evaluación del daño en el DNA espermático assessing sperm DNA damage. Actas Urol. Esp. 31: 120-131.

Duong A, Steinmaus C, McHale CM, Vaughan CP, et al. (2011). Reproductive and developmental toxicity of formaldehyde: A systematic review. Mutat. Res. 728: 118-138.

EPA (2011). Review of the Environmental Protection Agency's Draft IRIS Assessment of Formaldehyde. Available at [http://www.nap.edu/catalog/13142.html]. Accessed January 6, 2013.

Fernández JL, Muriel L, Rivero MT, Goyanes V, et al. (2003). The sperm chromatin dispersion test: A simple method for the determination of sperm DNA fragmentation. J. Androl. 24: 59-66.

Gil-Villa AM, Cardona-Maya WD and Cadavid-Jaramillo AP (2007). Early embryo death: Does the male factor play a role? Arch. Esp. Urol. 60: 1057-1068.

Golalipour MJ, Azarhoush R, Ghafari S, Gharravi AM, et al. (2007). Formaldehyde exposure induces histopathological and morphometric changes in the rat testis. Folia Morphol. 66: 167-171.

Golalipour MJ, Azarhoush R, Ghafari S, Davarian A, et al. (2009). Can formaldehyde exposure induce histopathologic and morphometric changes on rat kidney? Int. J. Morphol. 4: 1195-1200.

Gurel A, Coskun O, Armutcu F, Kanter M, et al. (2005). Vitamin E against oxidative damage caused by formaldehyde in frontal cortex and hippocampus: biochemical and histological studies. J. Chem. Neuroanat. 29: 173-178.

Heck HD, White EL and Casanova-Schmitz M (1982). Determination of formaldehyde in biological tissues by gas chromatography/mass spectrometry. Biomed. Mass Spectrom. 9: 347-353. 
IARC (1995). Formaldehyde. In: IARC Monographs on the Evaluation of Carcinogenic Risks to Humans. Wood, Dust and Formaldehyde. Vol. 62. International Agency for Research on Cancer, Lyon, 217-362.

Johannsen FR, Levinskas GJ and Tegeris AS (1986). Effects of formaldehyde in the rat and dog following oral exposure. Toxicol. Lett. 30: 1-6.

Lino-dos-Santos-Franco A, Correa-Costa M, Durão AC, de Oliveira AP, et al. (2011). Formaldehyde induces lung inflammation by an oxidant and antioxidant enzymes mediated mechanism in the lung tissue. Toxicol. Lett. 207: 278-285.

Liteplo RG, Beauchamp R, Meek ME and Chénier R (2002). Formaldehyde. In: Concise International Chemical Assessment Document 40 World Health Organization Geneva. Available at [http://www.who.int/ipcs/publications/ cicad/en/cicad40.pdf]. Accessed December 15, 2014.

Lu K, Boysen G, Gao L, Collins LB, et al. (2008). Formaldehyde-induced histone modifications in vitro. Chem. Res. Toxicol. 21: 1586-1593.

Lu K, Collins LB, Ru H, Bermudez E, et al. (2010). Distribution of DNA adducts caused by inhaled formaldehyde is consistent with induction of nasal carcinoma but not leukemia. Toxicol. Sci. 116: 441-451.

Majumder PK and Kumar VL (1995). Inhibitory effects of formaldehyde on the reproductive system of male rats. Indian J. Physiol. Pharmacol. 39: 80-82.

Manicardi GC, Tombacco A, Bizzarro D, Bianchi U, et al. (1998). DNA strand breaks in ejaculated human spermatozoa: comparison of susceptibility to the nick translation and terminal transferase assays. Histochem. J. 30: 33-39.

Somers MC and Cooper ND (2009). Air pollution and mutations in the germline: are humans at risk? Hum. Genet. 125: 119-130.

Tajaddini S, Ebrahimi S, Behnam B, Bakhtiyari M, et al. (2014). Antioxidant effect of manganese on the testis structure and sperm parameters of formalin-treated mice. Andrologia 46: 246-253.

Tang M, Xie Y, Yi Y and Wang W (2003). Effects of formaldehyde on germ cell of male mice. Wei Sheng Yan Jiu 32: 544-548.

Til HP, Woutersen RA, Feron VJ, Hollanders VH, et al. (1989). Two-year drinking water study of formaldehyde in rats. Food Chem. Toxicol. 27: 77-87.

Treulen F, Uribe P, Boguen R and Villegas JV (2015). Mitochondrial permeability transition increases reactive oxygen species production and induces DNA fragmentation in human spermatozoa. Hum. Reprod. 30: 767-776.

Vosoughi S, Khavanin A, Salehnia M, Asilian Mahabadi H, et al. (2012). Effects of simultaneous exposure to formaldehyde vapor and noise on mouse testicular tissue and sperm parameters. J. Health Scope 1: 110-117.

Wang HX, Zhou DX, Zheng LR, Zhang J, et al. (2012). Effects of paternal occupation exposure to formaldehyde on reproductive outcomes. J. Occup. Environ. Health 54: 518-524.

Ward WS (1993). Deoxyribonucleic acid loop domain tertiary structure in mammalian spermatozoa. Biol. Reprod. 48: 1193-1201.

Ward WS and Coffey DS (1991). DNA packaging and organization in the mammalian spermatozoa: comparison with somatic cells. Biol. Reprod. 44: 569-574.

WHO (World Health Organization) (1989). Environmental Health Criteria 89, Formaldehyde. Available at [http://www. inchem.org/documents/ehc/ehc/ehc89.htm]. Accessed January 5, 2013.

WHO (World Health Organization) (2000). Air Quality Guidelines for Europe. 2nd edn. Available at [http://www.euro. who.int/_data/assets/pdf_file/0005/74732/E71922.pdf]. Accessed January 10, 2013.

Zahra T, Tajik P, Fazelipour S and Taghva M (2007). Effect of formaldehyde injection in mice on testis function. Int. J. Pharmacol. 3: 421-424.

Zhang J, Zhou D and Wang H (2011). Effects of acute formaldehyde exposure on serum testosterone content and sexual behavior in adult male rats. Chin. J. Clin. 5: 9.

Zhou DX, Qiu SD, Zhang J, Tian H, et al. (2006). The protective effect of vitamin E against oxidative damage caused by formaldehyde in the testes of adult rats. Asian J. Androl. 8: 584-588.

Zhou DX, Zhang J and Wang H (2011). Assessment of the potential reproductive toxicity of long-term exposure of adult male rats to low-dose formaldehyde. Toxicol. Ind. Health 27: 581-598.

Zribi N, Chakroun NF, Elleuch H, Abdallah FB, et al. (2011). Sperm DNA fragmentation and oxidation are independent of malondialdheyde. Reprod. Biol. Endocrinol. 9: 47. 